\title{
Characterizing ecosystem water-use efficiency of croplands with eddy covariance measurements and MODIS products
}

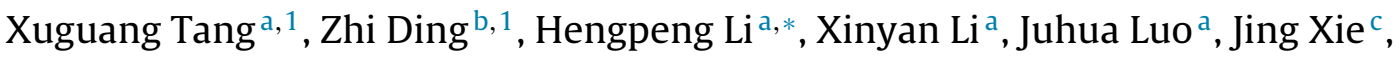 \\ Dongqiang Chen ${ }^{\mathrm{z}}$ \\ a Key Laboratory of Watershed Geographic Sciences, Nanjing Institute of Geography and Limnology, Chinese Academy of Sciences, Nanjing 210008, China \\ ${ }^{\mathrm{b}}$ Institute of Geographic Sciences and Natural Resources Research, Chinese Academy of Sciences, Beijing 100101, China \\ ${ }^{\mathrm{c}}$ Department of Geography, University of Zurich, Zurich, Switzerland
}

\section{A R T I C L E I N F O}

\section{Article history:}

Received 17 February 2015

Received in revised form

10 September 2015

Accepted 29 September 2015

Available online 18 October 2015

\section{Keywords:}

Water use efficiency

MODIS

Management practices

Carbon balance

\begin{abstract}
A B S T R A C T
How to quantify the variability in ecosystem water use efficiency (WUE) of croplands is of vital importance. Especially in the context of changing hydrologic environment, much attention need to be paid on how to use limited water to improve crop yield. However, the biophysical performances of environmental/biological controls, crop types, and effects of diverse farming practices on WUE remain unclear. Therefore, this study aims to address these questions through tower-based measurements from eddy covariance and satellite-based estimates from MODIS GPP and ET products at the two annual soybean/corn rotation fields. The results exhibited that temperature and solar radiation are the most important meteorological factors. MODIS WUE estimates captured the broad trend of 8-day tower-based observations. However, ecosystem WUE was overpredicted at the seedling stage and after harvest, and was severely underestimated at the peak periods of maize, which was mainly ascribed to the uncertainties in MODIS GPP. Finally, we evaluated the effects of two farming practices (conventional vs alternative) on WUE and carbon sequence (NEE). On annual time scale, WUE of both soybean and maize are improved obviously under the alternative management whereas contrasting effects are observed on NEE. But the overall carbon balance for both treatments is nearly identical over 2-year rotation.
\end{abstract}

(c) 2015 Elsevier B.V. All rights reserved.

\section{Introduction}

Water use efficiency (WUE) is one of the key parameters of ecohydrology and ecosystem management, which is also closely related to interactions between the carbon and water cycles in terrestrial ecosystems (Niu et al., 2011). Vegetation on Earth assimilates atmospheric $\mathrm{CO}_{2}$ through photosynthesis, which is inherently accompanied with the loss of water that regulates the mass-energy exchange between the biosphere and the atmosphere (Field et al., 1995; Berry et al., 2010). Therefore, ecosystem WUE is relevant to the reasonable utilization of water resource and survival strategies, as well as responses to changing hydrological environment (Tong et al., 2009; Kharrou et al., 2011; Ito and Inatomi, 2012). Especially for agriculture, WUE is important for agronomy and irrigation management that represents an expected crop yield at the expense of water supply.

\footnotetext{
* Corresponding author.

E-mail address: hpli@niglas.ac.cn (H. Li).

1 These authors contributed equally to this work.
}

Despite the consensus that increasing atmospheric $\mathrm{CO}_{2}$ concentration causes the temperature to rise, it may have substantial negative impacts on terrestrial ecosystems (Baker and Griffis, 2005). Higher temperature enhances plant evapotranspiration (ET) that will likely increase the frequency and intensity of drought. Meanwhile, it stretches out the growing season, as spring comes earlier and fall stays later, which can lead to increased water demand. With increasing urbanization, industrialization, and other demands on water, the pressure to reduce agricultural water use is also enhanced (Thenkabail et al., 2010). The question of how to improve WUE of croplands through appropriate farming practices such as conventional-till or no-till is critical.

At ecosystem level, continuous observations of carbon and water fluxes using eddy covariance technique can be used to characterize the variability in WUE by dividing gross primary production (GPP) with ET (Williams et al., 2012). By combining these fluxes with satellite-based remote sensing, it has become possible to upscale the spatiotemporal variability of land-surface exchanges at regional to global scales (Zhao et al., 2005; Jung et al., 2010; Tang et al., 2012). Although Tang et al. (2014) evaluated how global WUE of terrestrial ecosystems distributed and changed in the past decade 
using MODIS products on annual time scale, the consistencies with tower-based WUE at short time scales remain unclear. Meanwhile, it is important to understand how management practices affect the agriculture. This study aims to: (1) explore the underlying mechanisms of environmental/biological controls on the variability in WUE of soybean and maize; (2) evaluate the performance of MODIS WUE in capturing 8-day WUE dynamics at the two flux sites; (3) reveal the effects of different management practices on ecosystem WUE and NEE of the two farming systems.

\section{Methods and materials}

\subsection{Site description}

Both flux tower sites are located at the University of Minnesota's Rosemount Research and Outreach Center. Two fields are directly adjacent but separated by a road, with the same soil types, similar long-term cropping histories, and a regional phenology that usually starts in May and ends in late October. However, contrasting farming practices are implemented at the annual rotation of maize/soybean croplands (maize in the odd years and soybean in the even years). The south field (US-Bo1) is farmed conventionally, with fall tillage after harvest. While the north field (US-Ro3) is under an alternative management strategy. First, tillage intensity is reduced by using strip tillage instead of chisel plowing. Secondly, a spring oats cover crop in the soybean year is planted in early April, and then killed shortly after soybean planting. Further information can be seen in Baker and Griffis (2005) and Kalfas et al. (2011).

\subsection{Site-specific eddy covariance data}

Flux measurements at both sites started in late 2001 with a $10 \mathrm{~m}$ flux tower mounted in the center of each field. In this study, our analysis is based on continuous observations of land surface exchanges between 2004 and 2005 at US-Ro1 and US-Ro3 (http:// ameriflux.ornl.gov/). The level 4 product provides canopy-scale water vapor flux, $\mathrm{CO}_{2}$ flux, meteorological factors including solar radiation ( $\mathrm{Rg}$ ), air temperature (Ta), vapor pressure deficit (VPD), precipitation (P), and estimates of GPP derived from the measured NEE fluxes using the methodology proposed by Reichstein et al. (2005). Weekly data are used to keep consistent with the time intervals of MODIS products. The data were quality checked, and data gaps due to system failure or data rejection were filled using standardized methods to provide complete data sets (Moffat et al., 2007). Here we use the ecosystem-level definition which is relevant for evaluating ecosystem models as: WUE $=\mathrm{GPP} / \mathrm{ET}$. The seasonal trend was characterized by weekly WUE $\left(\mathrm{g} \mathrm{C} \mathrm{kg}^{-1} \mathrm{H}_{2} \mathrm{O}\right)$. The latent heat $\left(\mathrm{LE}, \mathrm{w} / \mathrm{m}^{2}\right.$ ) fluxes were used to obtain water loss (ET, $\mathrm{mm} /$ day) by multiplying a factor of 0.035 .

\subsection{MODIS products and processing}

Satellite remote sensing of vegetation can be used to derive ecosystem WUE because both processes of $\mathrm{CO}_{2}$ sequestration through photosynthesis and loss of water by ET are closely related with biophysical properties and environmental factors (Bacon, 2004; Reichstein et al., 2014). Currently, NASA TERRA and AQUA MODIS-based estimates of GPP and ET have been developed and improved greatly during the past decade which can also be obtained to quantify large-scale WUE (Lu and Zhuang, 2010; Tang et al., 2014). Zhao et al. (2005) rectified the GPP products by improving the data processing methods and modifying parameters in the algorithm used, which generated the improved Collection 5 MOD17 estimates. In addition, Mu et al. (2011) improved a satellite remote sensing-based ET algorithm to assess global terrestrial ET using MODIS and global meteorology data. These data can be obtained freely from http://www.ntsg.umt.edu/project/mod16. Remotely sensed WUE can be calculated using the ratio of GPP to ET. The 8-day composite Land Surface Reflectance (MOD09A1) data from one MODIS pixel where the flux towers lay were downloaded from the Oak Ridge National Laboratory's Distributed Active Archive Center web site (http://daac.ornl.gov/MODIS/). Then, this study calculated time-series vegetation index (EVI) data (Huete et al., 2002).

\section{Results and discussion}

\subsection{Seasonal variations in WUE and the environmental/biological controls}

To investigate crop WUE in a farmland, it is necessary to understand the seasonal variations in key environmental factors that directly affect plant functional properties related to carbon and water cycles. Due to the spatial proximity, two flux sites have the same meteorological conditions. Seasonal patterns of WUE, GPP and ET with the environmental/biological controls including $\mathrm{R}_{\mathrm{g}}, \mathrm{T}_{\mathrm{a}}, \mathrm{VPD}, \mathrm{P}$ and EVI observed at US-Ro1 and US-Ro3 during 2004 and 2005 are showed in Figs. 1 and 2. The 8-day variations in WUE, GPP and ET strongly covary with temperature and solar radiation. Moreover, Pearson's correlation analysis proved that $\mathrm{T}_{\mathrm{a}}$ performed the highest positive correlation with WUE throughout the four year's measurements for two cropping systems. Except winter months, VPD keeps high around the year. Both of these sites entirely depend on rainfall. Fortunately, approximately $63 \%$ of the annual precipitation occurred during the cultivation-period at these crop sites. Time-series MODIS-derived EVI data also exhibited seasonal dynamics of crop growth. The alternative management with a spring oats cover crop at US-Ro3 is well illustrated in Figs. $1 \mathrm{f}$ and 2, with a deep trough during about WOY 23. This modification also brings us two peaks of GPP and WUE for oats and soybean, respectively.

Outside the growing season of croplands, GPP and WUE are nearly zero owing to harvest; however, seasonal patterns of ET are obviously different. Fig. 2 revealed that as temperature rises in the springtime, soil evaporation goes on rapidly without photosynthetic activities. Then, it reaches the peak during peak growth, and declines after crop senescence or harvest. In addition, both the maximum and amplitude of WUE are higher in maize than those in soybean. Although annual mean ET of maize and soybean are nearly equivalent at the two sites, as a $\mathrm{C}_{4}$ plant, maize has higher ability to assimilate $\mathrm{CO}_{2}$ and hence leads to higher WUE than soybean, a $\mathrm{C}_{3}$ plant.

\subsection{Comparisons of WUE from flux tower measurements and MODIS estimates}

Fig. 2 compared the seasonal variations in tower-based WUE with the MODIS estimates at the two flux sites. As changes in $\mathrm{WUE}_{\mathrm{EC}}$, WUE $\mathrm{RS}_{\mathrm{R}}$ only captured the broad trends, two apparent discrepancies still existed. On one hand, $W_{U E}$ greatly overpredict the variability in WUE at the beginning and ending of crop-growth period, especially at US-Ro1. On the other hand, WUE $\mathrm{EC}_{\mathrm{EC}}$ during the peak periods are severely underestimated, especially for maize cropland. In addition, WUE $\mathrm{RS}_{\mathrm{R}}$ cannot accurately capture the drastic variation in the transition from oats to soybean at US-Ro3. Therefore, seasonal patterns of GPP and ET from flux measurements and MODIS products are compared to explore the potential reasons. As shown in Fig. 3, MODIS ET promised reasonably well with measured ET during 2004 and 2005 at the crop sites. Except soybean year at US-Ro1, the discrepancies are less than $10 \%$ for the other 3 site-years. However, large differences existed in 8-day EC_GPP and 

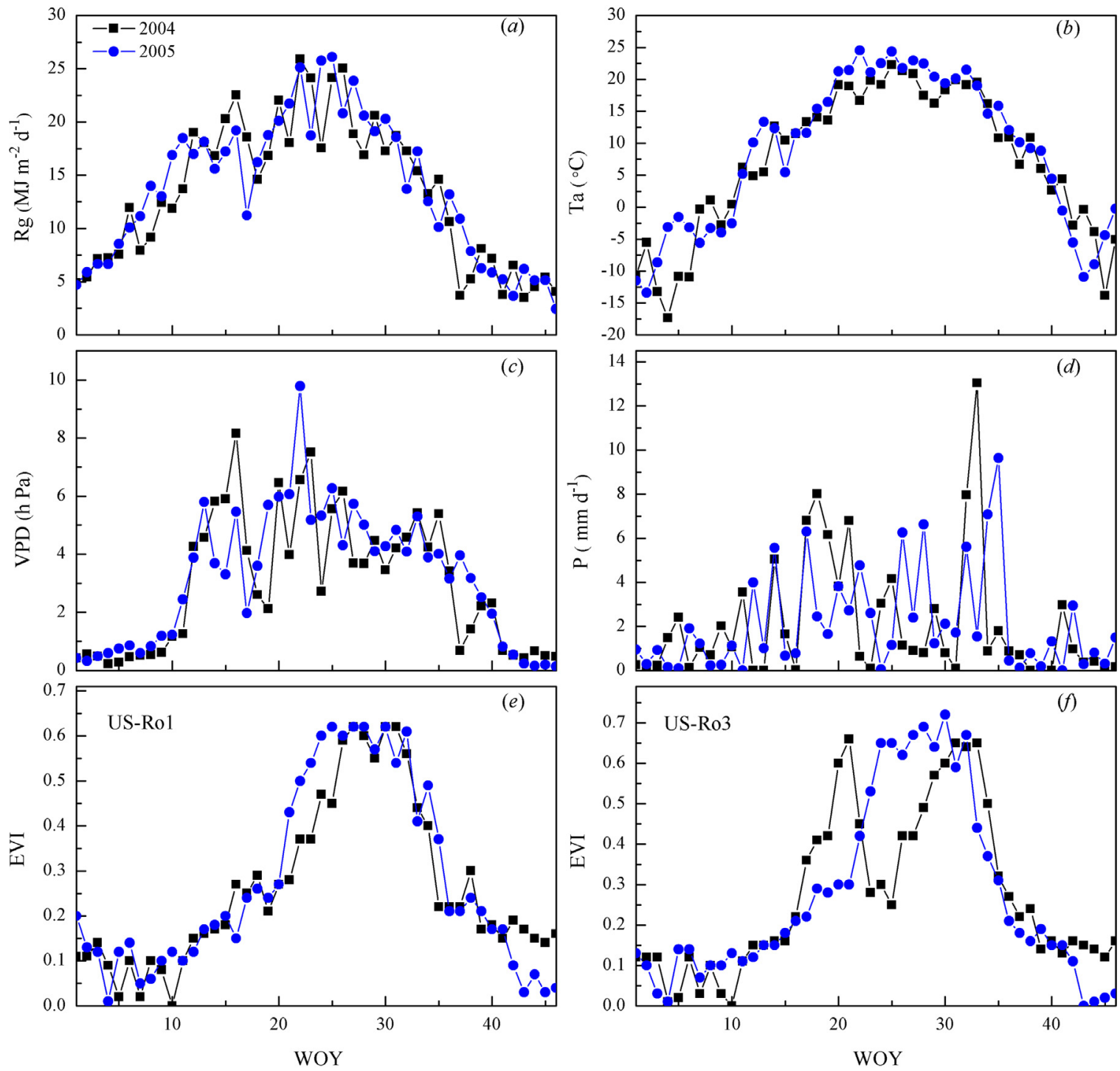

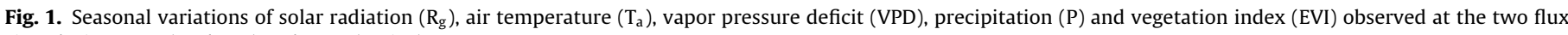
sites during 2004 (soybean) and 2005 (maize).

MOD_GPP. Similar to the variations in WUE, GPP was overestimated at the seedling stage and after harvest, and was underestimated during the peak period, particularly for maize with the percentage deviations of $-49.8 \%$ and $-48.9 \%$ at the two sites. The seasonal variations in MOD_GPP during 2004 and 2005 were nearly identical, which neglected the differences between $C_{3}$ and $C_{4}$. Owing to these problems, annual mean WUEs of soybean are overestimated by $82.3 \%$ and $14.7 \%$, respectively; whereas annual mean WUEs of maize are underestimated by $-21.2 \%$ and $-30.9 \%$, respectively.

Ecosystem WUE of maize is obviously higher than that of soybean, which is mainly attributed to physiological pathways, as well as leaf structures are different between maize and soybean (Gitelson et al., 2006). $C_{4}$ crops are generally found to have high phosphoenolpyruvate carboxylase activity (Still et al., 2003). In addition, many studies have found that $\mathrm{C}_{4}$ plants exhibited increasing WUE in response to rising $\mathrm{CO}_{2}$ with reductions in stomatal conductance and transpirational water loss compared to $C_{3}$ species (Manzoni et al., 2011; Traore et al., 2014). Nevertheless, WUE $E_{R S}$ only captured the broad trend of WUE. Chen et al. (2015) indicated that a reasonable representation of crop phenology in land surface models was necessary to accurately simulate energy, water and carbon budgets. In this study, time-series MODIS EVI data exhibited strong potential for remote quantification. Thus, an alternative method to track the variability in WUE can be explored later.

\subsection{Effects of management practices on WUE and NEE}

There has been much interest in the role that agricultural practices might act in the processes of carbon and water fluxes. Management methods were proposed to increase carbon sequestration (Jones and Donnelly, 2004; Baker and Griffis, 2005), but recent studies have questioned whether no-till management can reach this goal (Baker et al., 2007; Ogle et al., 2012). Especially, effects of these farming practices on WUE remain unclear, which is important for proper recommendations or policy changes. Fig. 4 illustrated the responses of annual mean WUE and NEE to conventional tillage, and alternative management with strip tillage and cover cropping at the two soybean/maize rotation fields. At annual time scale, WUE of both soybean and maize are improved obviously under the alternative management, especially for soybean. Spring oats cover prior to soybean planting contributed to the remarkable WUE improvement. But the effects of alternative management on carbon sequestration are contrasting. Soybean field at US-Ro3 assimilates more $\mathrm{CO}_{2}$ than that at US-Ro1, and it is inspiring to 


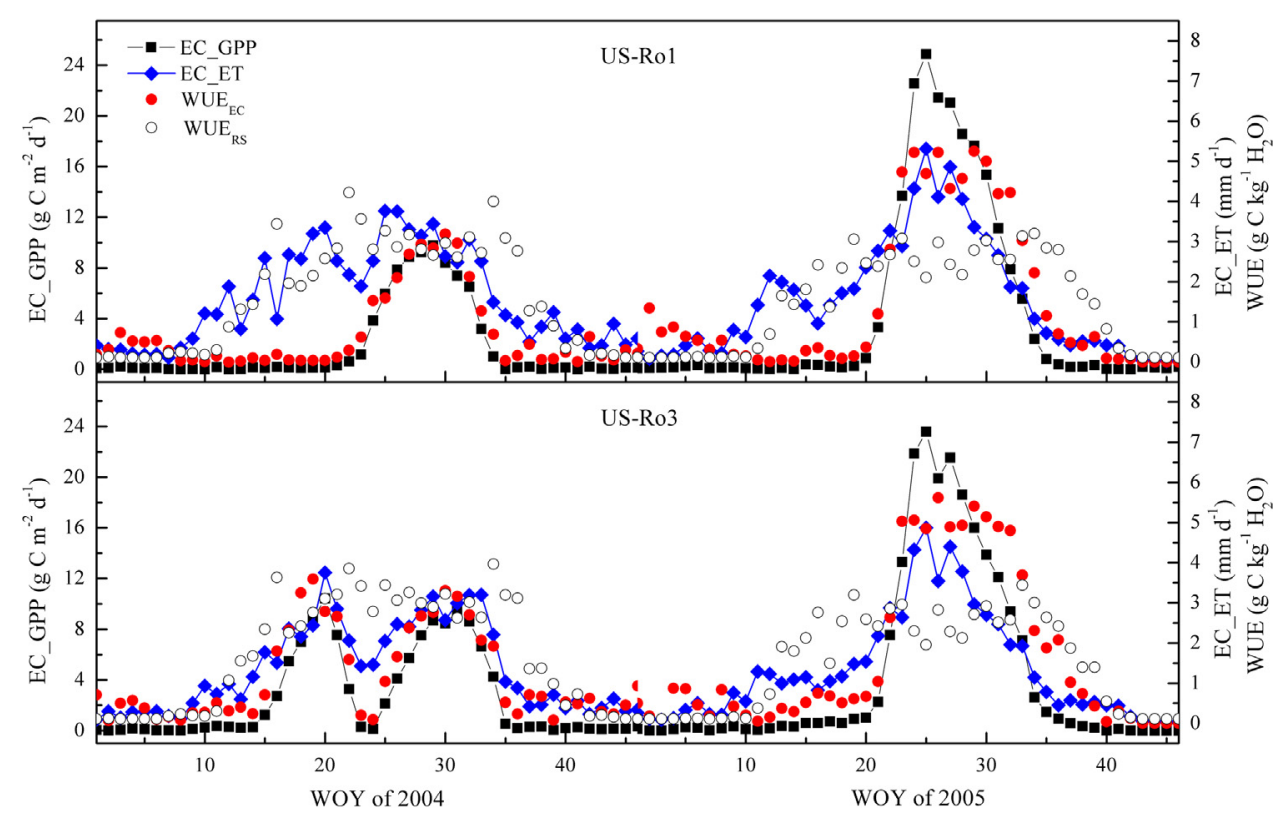

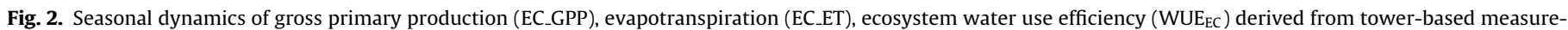
ments and MODIS WUE estimates (WUE $\mathrm{RS}_{\mathrm{S}}$ ) at the two flux tower sites US-Ro1 and US-Ro3.

see that the role even changed from carbon source to carbon sink. In a surprise twist, NEE of maize under strip tillage decreased by $-24.6 \%$. Over 2-year rotation, the overall carbon sequestration for two treatments is nearly equivalent.

The conventional tillage is susceptible to soil loss and surface runoff during intense spring rains, whereas crop residues in the notill or reduced-till field allow more water to infiltrate into the soil. Meanwhile, the residue mulch further conserves water by reducing evaporation from the soil surface. Seasonal variations of ET in Fig. 2 also certify this point. All these may be beneficial to the WUE improvement for croplands. Although many studies considered an increase in yield with adoption of no-till management (Beyaert et al., 2002; Grandy et al., 2006), no change or even a decrease in crop yield were also found in recent researches (Drury et al., 2003; Ogle et al., 2012; Powlson et al., 2014). Declines in yields are often attributed to cool and wet climatic conditions. Crop growth may be hindered in spring due to a surface residue layer under no-till management that depresses temperatures in the soil relative to full tillage systems (Al-Kaisi and Yin, 2005; Olchin et al., 2008; Varela et al., 2014). Besides this, crop residue decay will release a certain

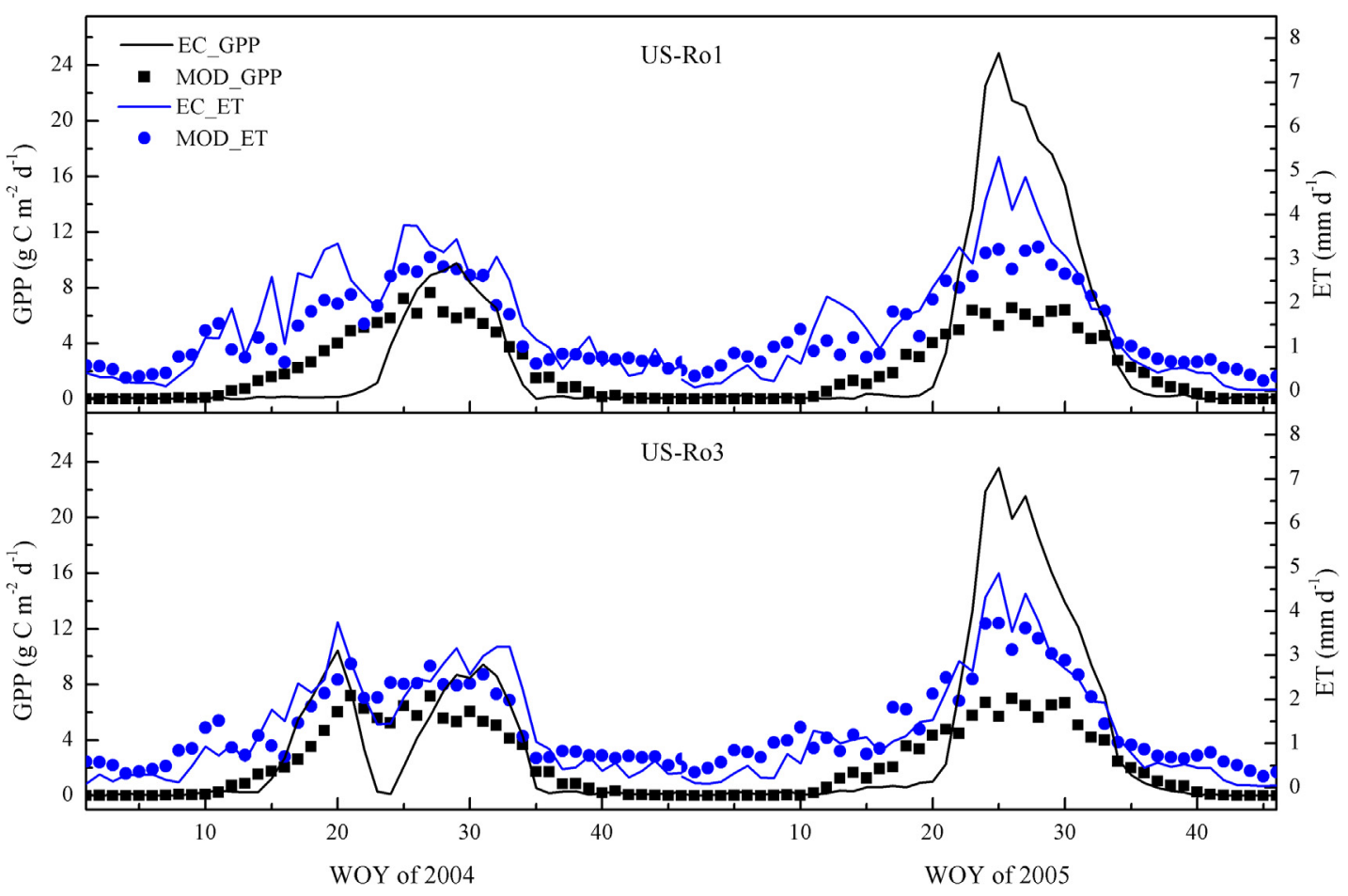

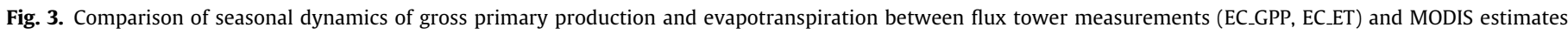
(MOD_GPP, MOD_ET) at the two flux tower sites. 


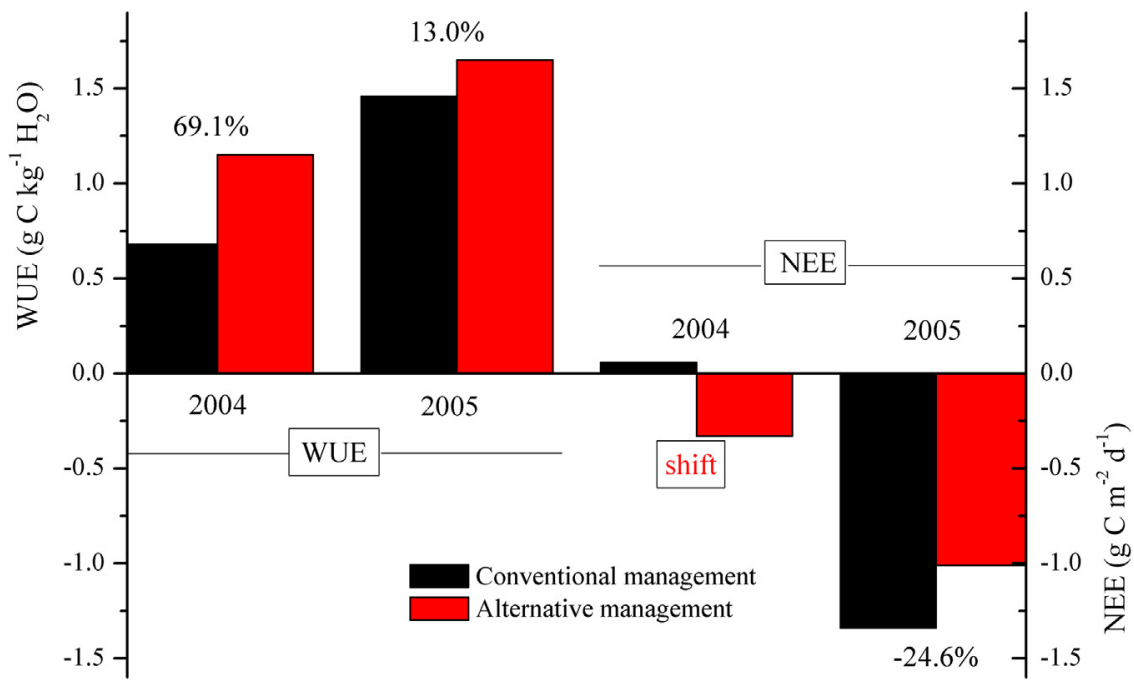

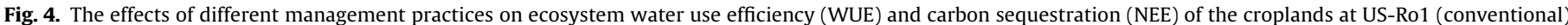
and US-Ro3 (alternative).

amount of $\mathrm{CO}_{2}$ through respiration, which also contributes to the decrease of carbon sequestration in the maize year.

\section{Conclusions}

Based on flux measurements of carbon and water fluxes at the two soybean/maize rotation fields under different farming practices, we find that MODIS-derived EVI data exhibited a consistent tendency with temporal changes in WUE, GPP and ET, which also well depicted the alternative management with a spring oats cover crop in the soybean year at Ro3. Remote-sensing approaches can be a powerful tool for quantifying ecosystem WUE at larger scales. Although MODIS estimates of WUE could capture the broad trend of tower-based measurements, WUE was overpredicted at the beginning and ending of crop-growth period and was severely underestimated at the peak periods of maize under two treatments. Large uncertainties in MODIS GPP product might lead to these discrepancies. Owing to different physiological pathways, the $C_{3}$ and $\mathrm{C}_{4}$ plants need to be distinguished for monitoring vegetation production accurately. Tracking the variability in WUE by use of MODIS EVI data may be a solution. We also find that annual WUE of both soybean and maize are improved obviously under the alternative management. In spite of contrasting responses of NEE, the overall $\mathrm{C}$ balance for two treatments are nearly identical over 2-year rotation. To increase the carbon sequestration of croplands, a fallplanted cover crop such as winter wheat may be more effective.

\section{Acknowledgements}

This study was jointly supported by the National Natural Science Foundation of China $(41401221,41271500)$, the Key Research Program of the Chinese Academy of Sciences (KZZD-EW-10-04) and the Natural Science Foundation of Jiangsu Province, China (BK20141058). The AmeriFlux network provided us the EC data. We also thank China Scholarship Council and Swiss Government Excellence Scholarship.

\section{References}

Al-Kaisi, M.M.,Yin, X.,2005. Tillage and crop residue effects on soil carbon and carbon dioxide emission in corn-soybean rotations. J. Environ. Qual. 34, 437-445.

Bacon, M.A., 2004. [Water Use Efficiency in Plant Biology] What is Water-Use Efficiency? Blackwell Publishing, Oxford, pp. 27-41.
Baker, J.M., Griffis, T.J., 2005. Examining strategies to improve the carbon balance of corn/soybean agriculture using eddy covariance and mass balance techniques. Agric. For. Meteorol. 128, 163-177.

Baker, J.M., Ochsner, T.E., Venterea, R.T., Griffis, T.J., 2007. Tillage and soil carbon sequestration - what do we really know? Agric. Ecosyst. Environ. 118, 1-5.

Berry, J.A., Beerling, D.J., Franks, P.J., 2010. Stomata: key players in the earth system, past and present. Curr. Opin. Plant Biol. 13, 232-239.

Beyaert, R.P., Schott, J.W., White, P.H., 2002. Tillage effects on corn production in a coarse-textured soil in southern Ontario. Agron. J. 94, 767-774.

Chen, M., Griffis, T.J., Baker, J., Wood, J.D., Xiao, K., 2015. Simulating crop phenology in the Community Land Model and its impact on energy and carbon fluxes. J. Geophys. Res. 120, 310-325.

Drury, C.F., Tan, C.S., Reynolds, W.D., Welacky, T.W., Weaver, S.E., Hamill, A.S., Vyn, T.J., 2003. Impacts of zone tillage and red clover on corn performance and soi physical quality. Soil Sci. Soc. Am. J. 67, 867-877.

Field, C.B., Jackson, R.B., Mooney, H.A., 1995. Stomatal responses to increased $\mathrm{CO}_{2}$ : implications from the plant to the global scale. Plant Cell Environ. 18, 1214-1225.

Gitelson, A.A., Viña, A., Verma, S.B., Rundquist, D.C., Arkebauer, T.J., Keydan, G., Leavitt, B., Ciganda, V., Burba, G.G., Suyker, A.E., 2006. Relationship between gross primary production and chlorophyll content in crops: implications for the synoptic monitoring of vegetation productivity. J. Geophys. Res. 111 (D8).

Grandy, A.S., Loecke, T.D., Parr, S., Robertson, G.P., 2006. Long-term trends in nitrous oxide emissions, soil nitrogen, and crop yields of till and no-till cropping systems. J. Environ. Qual. 35, 1487-1495.

Huete, A., Didan, K., Miura, T., Rodriguez, E.P., Gao, X., Ferreira, L.G., 2002. Overview of the radiometric and biophysical performance of the MODIS vegetation indices. Remote Sens. Environ. 83 (1), 195-213.

Ito, A., Inatomi, M., 2012. Water-use efficiency of the terrestrial biosphere: a mode analysis focusing on interactions between the global carbon and water cycles. J. Hydrometeorol. 13, 681-694.

Jones, M.B., Donnelly, A., 2004. Carbon sequestration in temperate grassland ecosystems and the influence of management, climate and elevated $\mathrm{CO}_{2}$. New Phytol. $164,423-439$.

Jung, M., Reichstein, M., Ciais, P., Seneviratne, S.I., Sheffield, J., Goulden, M.L., et al., 2010. Recent decline in the global land evapotranspiration trend due to limited moisture supply. Nature 461, 951-954.

Kalfas, J.L., Xiao, X., Vanegas, D.X., Verma, S.B., Suyker, A.E., 2011. Modeling gross primary production of irrigated and rain-fed maize using MODIS imagery and $\mathrm{CO}_{2}$ flux tower data. Agric. For. Meteorol. 151, 1514-1528.

Kharrou, M.H., Er-Raki, S., Chehbouni, A., Duchemin, B., Simonneaux, V., LePage, M. Ouzine, L., Jarlan, L., 2011. Water use efficiency and yield of winter wheat under different irrigation regimes in a semi-arid region. Agric. Sci. 2, 273.

Lu, X.L., Zhuang, Q.L., 2010. Evaluating evapotranspiration and water-use efficiency of terrestrial ecosystems in the conterminous United States using MODIS and Ameriflux data. Remote Sens. Environ. 114, 1924-1939.

Manzoni, S., Vico, G., Katul, G., Fay, P.A., Polley, W., Palmroth, S., Porporato, A. 2011. Optimizing stomatal conductance for maximum carbon gain under water stress: a meta-analysis across plant functional types and climates. Funct. Ecol. 25, 456-467.

Moffat, A.M., Papale, D., Reichstein, M., Hollinger, D.Y., Richardson, A.D., Barr A.G., Beckstein, C., Braswell, B.H., Churkina, G., Desai, A.R., Falge, E., Gove, J.H., Heimann, M., Hui, D., Jarvis, A.J., Kattge, J., Noormets, A., 2007. Comprehensive comparison of gap-filling techniques for eddy covariance net carbon fluxes. Agric. For. Meterol. 147, 209-232.

Mu, Q., Zhao, M., Running, S.W., 2011. Improvements to a MODIS global terrestrial evapotranspiration algorithm. Remote Sens. Environ. 115, 1781-1800. 
Niu, S., Xing, X., Zhang, Z., Xia, J., Zhou, X., Song, B., Li, L.H., Wan, S.Q., 2011. Water use efficiency in response to climate change-from leaf to ecosystem in a temperate steppe. Glob. Change Biol. 17, 1073-1082.

Ogle, S.M., Swan, A., Paustian, K., 2012. No-till management impacts on crop productivity, carbon input and soil carbon sequestration. Agric. Ecosyst. Environ. 149, 37-49.

Olchin, G.P., Ogle, S., Frey, S.D., Filley, T.R., Paustian, K., Six, J., 2008. Residue carbon stabilization in soil aggregates of no-till and tillage management of dryland cropping systems. Soil Sci. Soc. Am. J. 72, 507-513.

Powlson, D.S., Stirling, C.M., Jat, M.L., Gerard, B.G., Palm, C.A., Sanchez, P.A., Cassman, K.G., 2014. Limited potential of no-till agriculture for climate change mitigation. Nat. Clim. Change 4, 678-683.

Reichstein, M., Falge, E., Baldocchi, D., Papale, D., Aubinet, M., Berbigier, P., et al., 2005. On the separation of net ecosystem exchange into assimilation and ecosystem respiration: review and improved algorithm. Glob. Change Biol. 11, 1424-1439.

Reichstein, M., Bahn, M., Mahecha, M.D., Kattge, J., Baldocchi, D.D., 2014. Linking plant and ecosystem functional biogeography. PNAS 111, 13697-13702.

Still, C.J., Berry, J.A., Collatz, G.J., DeFries, R.S., 2003. Global distribution of $C_{3}$ and $C_{4}$ vegetation: carbon cycle implications. Glob. Biogeochem. Cycles 17, 6.

Tang, X.G., Wang, Z.M., Liu, D.W., Song, K.S., Jia, M.M., Dong, Z.Y., Munger, J.W., Hollinger, D.Y., Bolstad, P.V., Goldstein, A.H., Desai, A.R., Dragoni, D., Liu, X., 2012. Estimating the net ecosystem exchange for the major forests in the northern United States by integrating MODIS and AmeriFlux data. Agric. For. Meteorol. $156,75-84$.
Tang, X., Li, H., Desai, A.R., Nagy, Z., Lou, J., Kolb, T.E., Olioso, A., Xu, X., Yao, L., Kutsch, W., Pilegaard, K., Köstner, B., Ammann, C., 2014. How is water-use efficiency of terrestrial ecosystems distributed and changing on Earth? Sci. Rep. 4, 7483.

Thenkabail, P.S., Hanjra, M.A., Dheeravath, V., Gumma, M., 2010. A holistic view of global croplands and their water use for ensuring global food security in the $21 \mathrm{st}$ century through advanced remote sensing and non-remote sensing approaches. Remote Sens. 2, 211-261.

Tong, X.J., Li, J., Yu, Q., Qin, Z., 2009. Ecosystem water use efficiency in an irrigated cropland in the North China Plain. J. Hydrol. 374, 329-337.

Traore, A.K., Ciais, P., Vuichard, N., MacBean, N., Dardel, C., Poulter, B., Piao, S., Fisher J.B., Viovy, N., Jung, M., Myneni, R., 2014. 1982-2010 Trends of light use efficiency and inherent water use efficiency in African vegetation: sensitivity to climate and atmospheric $\mathrm{CO}_{2}$ concentrations. Remote Sens. 6, 8923-8944.

Varela, M.F. Scianca, C.M., Taboada, M.A., Rubio, G, 2014. Cover crop effects on soybean residue decomposition and P release in no-tillage systems of Argentina. Soil Till. Res. 143, 59-66.

Williams, C., Reichstein, M., Buchmann, N., Baldocchi, D., Beer, C., Schwalm, C., Wohlfahrt, G., Hasler, N., Bernhofer, C., Foken, T. Papalev, D., Schymanski, S. Schaefer, K., 2012. Climate and vegetation controls on the surface water balance: synthesis of evapotranspiration measured across a global network of flux towers. Water Resour. Res. 48, W06523.

Zhao, M., Heinsch, F.A., Nemani, R.R., Running, S.W., 2005. Improvements of the MODIS terrestrial gross and net primary production global data set. Remote Sens. Environ. 95, 164-176. 